\title{
Induction of eosinophil apoptosis by hydrogen peroxide promotes the resolution of allergic inflammation
}

\author{
AC Reis ${ }^{1,2,8}$, AL Alessandri ${ }^{3,8}$, RM Athayde ${ }^{1,2}$, DA Perez ${ }^{1,2}$, JP Vago ${ }^{4}$, TV Ávila ${ }^{5}$ TP T Ferreira ${ }^{6}$, ACS de Arantes ${ }^{6}$, D de Sá Coutinho ${ }^{6}$, \\ MA Rachid ${ }^{7}$, LP Sousa ${ }^{4}$, MA Martins ${ }^{6}$, GB Menezes ${ }^{1}$, AG Rossi $^{3}$, MM Teixeira ${ }^{2}$ and V Pinho ${ }^{*, 1,2}$
}

Eosinophils are effector cells that have an important role in the pathogenesis of allergic disease. Defective removal of these cells likely leads to chronic inflammatory diseases such as asthma. Thus, there is great interest in understanding the mechanisms responsible for the elimination of eosinophils from inflammatory sites. Previous studies have demonstrated a role for certain mediators and molecular pathways responsible for the survival and death of leukocytes at sites of inflammation. Reactive oxygen species have been described as proinflammatory mediators but their role in the resolution phase of inflammation is poorly understood. The aim of this study was to investigate the effect of reactive oxygen species in the resolution of allergic inflammatory responses. An eosinophilic cell line (Eol-1) was treated with hydrogen peroxide and apoptosis was measured. Allergic inflammation was induced in ovalbumin sensitized and challenged mouse models and reactive oxygen species were administered at the peak of inflammatory cell infiltrate. Inflammatory cell numbers, cytokine and chemokine levels, mucus production, inflammatory cell apoptosis and peribronchiolar matrix deposition was quantified in the lungs. Resistance and elastance were measured at baseline and after aerosolized methacholine. Hydrogen peroxide accelerates resolution of airway inflammation by induction of caspase-dependent apoptosis of eosinophils and decrease remodeling, mucus deposition, inflammatory cytokine production and airway hyperreactivity. Moreover, the inhibition of reactive oxygen species production by apocynin or in gp91 ${ }^{\text {phox }-I-}$ mice prolonged the inflammatory response. Hydrogen peroxide induces Eol-1 apoptosis in vitro and enhances the resolution of inflammation and improves lung function in vivo by inducing caspase-dependent apoptosis of eosinophils.

Cell Death and Disease (2015) 6, e1632; doi:10.1038/cddis.2014.580; published online 12 February 2015

Eosinophils express numerous receptors and secrete a wide variety of inflammatory mediators that influence many innate and adaptive immune responses. These multifunctional cells are important in the defense against helminth infection and are involved in the pathogenesis of many eosinophilic dominant allergic diseases. ${ }^{1}$ High levels of eosinophil granule proteins (such as major basic protein (MBP)) have been found in bronchoalveolar lavage fluid from patients with asthma and evidence indicates that high-concentration granule products have contributed to the development of airway hyperreactivity (AHR), a cardinal feature of asthma. ${ }^{2}$ Asthma is an inflammatory disease of the airways with participation of many cell types including leukocytes especially eosinophils and lymphocytes. ${ }^{3,4}$ Activation of these cells (mainly lymphocytes) leads to the release of proinflammatory mediators and cytokines such as leukotriene $\mathrm{B}_{4}$, interleukin-4 (IL-4), interleukin-5 (IL-5), interleukin-9 (IL-9), interleukin-13 (IL-13) and colony-stimulating factor granulocyte-macrophage (GM-CSF) ${ }^{3,5-7}$ Investigations using preclinical animal models of asthma and clinical studies in patients with asthma have demonstrated that the presence of eosinophils in the lungs are associated with epithelial damage, goblet cell hyperplasia, smooth muscle hypertrophy and airway hyperresponsiveness resulting in airflow limitation which can be fatal. ${ }^{3,8-10}$ Recently, anti-IL-5 treatment has been shown to ameliorate lung function in patients with eosinophilic asthma. ${ }^{11}$

Apoptosis of leukocytes is regarded as an important process for the successful resolution of inflammatory responses. Reduced eosinophil apoptosis in bronchoalveolar lavage (BAL) fluid has been shown to correlate positively with severity of asthma.,12-14 Indeed, defective leukocyte apoptosis and subsequent removal of apoptotic cells by

\footnotetext{
${ }^{1}$ Laboratório de Resolução da Resposta Inflamatória, Departamento de Morfologia, Instituto de Ciências Biológicas, Universidade Federal de Minas Gerais, Belo Horizonte, Brazil; 'Laboratório de Imunofarmacologia, Departamento de Bioquímica e Imunologia, Instituto de Ciências Biológicas, Universidade Federal de Minas Gerais, Belo Horizonte, Brazil; ${ }^{3}$ Medical Research Council Centre for Inflammation Research, The Queen's Medical Research Institute, University of Edinburgh, Edinburgh, Scotland, UK; ${ }^{4}$ Laboratório de Sinalização na Inflamação, Departamento de Análises Clínicas e Toxicológicas, Faculdade de Farmácia, Universidade Federal de Minas Gerais, Belo Horizonte, Brazil; ${ }^{5}$ Departamento de Microbiologia, Instituto de Ciências Biológicas, Universidade Federal de Minas Gerais, Belo Horizonte, Brazil; ${ }^{6}$ Laboratório de Inflamação, Instituto Oswaldo Cruz, FIOCRUZ, Rio de Janeiro, Brazil and ${ }^{7}$ Laboratório de Patologia Geral, Instituto de Ciências Biológicas, Universidade Federal de Minas Gerais, Belo Horizonte, Brazil

${ }^{*}$ Corresponding author: V Pinho, Departamento de Morfologia, Instituto de Ciências Biológicas, Universidade Federal de Minas Gerais. Av. Antonio Carlos, 6627 Pampulha, Belo Horizonte, MG, 31270-901, Brazil. Tel/Fax: +55 313409 2996; E-mail: vpinho@icb.ufmg.br

${ }^{8}$ These authors contributed equally to this work.

Abbreviations: CAT, catalase; SOD, superoxide dismutase; MBP, eosinophil granule proteins; AHR, airway hyperreactivity; ROS, reactive oxygen species; RNS, Reactive nitrogen species; OVA, ovalbumin; EPO, eosinophil peroxidase

Received 01.8.14; revised 07.11.14; accepted 19.11.14; Edited by G Amarante-Mendes
} 
phagocytes is thought to be important for the initiation and propagation of chronic inflammatory diseases such as asthma. ${ }^{15}$ Therefore, a balance in the tissue microenvironment between pro- and antiapoptotic signals is likely to greatly influence the load of eosinophils in the asthmatic lung. ${ }^{16}$ Thus, there is a great interest in understanding the mechanisms responsible for the elimination of eosinophils and other leukocytes and inactivation of proinflammatory mediators in inflammatory sites. ${ }^{17}$

Several molecular pathways have been shown to modulate the survival and death of leukocytes at sites of inflammation, including reactive oxygen species (ROS). ${ }^{18} \mathrm{ROS}$ are a family of molecules containing oxygen and includes hydrogen peroxide $\left(\mathrm{H}_{2} \mathrm{O}_{2}\right)$, superoxide $\mathrm{O}_{2}^{-}$, hydroxyl radical $(\mathrm{OH})$ and nitric oxide (NO). ${ }^{19}$ In inflammatory conditions, ROS are increased as they help in neutralizing invading organisms during infection either directly or indirectly by formation of extracellular traps (ETs). ${ }^{20}$ ROS have traditionally been regarded as quintessentially proinflammatory. However, evidence for ROS-mediated anti-inflammatory actions has been described. ${ }^{21}$ The importance for ROS production in the context of infection can be exemplified in patients with chronic granulomatous disease (CGD) where defective production in ROS results in multiple infections and often early death. ${ }^{22,23}$ Furthermore, studies in mouse models have shown that NADPH oxidase is key for regulating lung inflammation and injury as well as NF- $\mathrm{BB}$ activation and downstream cytokine production in response to LPS. ${ }^{24}$ More recently, our group has demonstrated that NADPH oxidase-derived $\mathrm{H}_{2} \mathrm{O}_{2}$ is directly linked to induction of apoptosis of neutrophils and resolution of inflammation in a model of antigen-induced arthritis. ${ }^{18}$ However, the role of ROS in the context of the resolution of allergic inflammation is still unknown.

Here, we evaluated whether $\mathrm{H}_{2} \mathrm{O}_{2}$ drives apoptosis of eosinophils and thereby influences the resolution of established eosinophilic inflammation and reduction of airflow obstruction. Our study provides evidence that $\mathrm{H}_{2} \mathrm{O}_{2}$ is released during allergic inflammation in a gp $91^{\text {phox - / - }}$-dependent manner and induces a caspase-dependent proapoptotic effect in eosinophils, thus having a crucial role in the resolution of allergic inflammation.

\section{Results}

Kinetics of inflammation response after asthma induction in mice. We used a well-established murine model of asthma previously described by Stock et al. ${ }^{25}$ In this model, the inflammatory response was characterized by accumulation of leukocytes detectable at $12 \mathrm{~h}$ and that reached maximal at $24-48 \mathrm{~h}$ after challenge with OVA (Supplementary Figure 1A). There was predominant accumulation of neutrophils at $12 \mathrm{~h}$ after antigenic challenge (Supplementary Figure 1B). Twenty-four hours after challenge, the number of neutrophils dropped and there was increased accumulation of eosinophils. The natural resolution of eosinophilic inflammation was initiated at $48 \mathrm{~h}$ and virtually completed at $72 \mathrm{~h}$ after antigen challenge (Supplementary Figure 1C). Likewise, similar results were obtained in an allergic pleurisy model in which there is also acute self-resolving eosinophilic inflammation (Supplementary Figure 2A). Importantly, the increased number of mononuclear cells at $12 \mathrm{~h}$ and $48 \mathrm{~h}$ after antigen challenge coincided with the decrease of neutrophils and eosinophils, respectively (Supplementary Figure 1D).

Treatment with $\mathrm{H}_{2} \mathrm{O}_{2}$ or SOD decreases eosinophil accumulation in asthma models. Next experiments were designed to investigate the ability of $\mathrm{H}_{2} \mathrm{O}_{2}$ to resolve eosinophilic inflammation in vivo. We treated mice with SOD or $\mathrm{H}_{2} \mathrm{O}_{2} 24 \mathrm{~h}$ after OVA challenge, a time point at which the number of neutrophils is close to basal levels and eosinophil numbers are maximal. Treatment with SOD, which increases production of endogenous $\mathrm{H}_{2} \mathrm{O}_{2}$, or exogenous $\mathrm{H}_{2} \mathrm{O}_{2}$ treatment decreased the number of eosinophils in the BAL (Figure 1a) and reduced the levels of eosinophilic peroxidase (EPO) in the lung (Figure 1b). Treatment with catalase, which degrades $\mathrm{H}_{2} \mathrm{O}_{2}$, prevented the proresolving effects of SOD (Figures $1 \mathrm{a}$ and $\mathrm{b}$ ). The lung parenchyma of challenged mice exhibited intense infiltration of inflammatory cells and loss of pulmonary architecture $48 \mathrm{~h}$ after antigen challenge when compared with the control group (PBS) (Figures $1 \mathrm{c}$ and d). Mice that received $\mathrm{H}_{2} \mathrm{O}_{2}$ at $24 \mathrm{~h}$ showed reduced parenchymal inflammation (Figure 1e). Likewise, treatment with SOD was associated with less parenchymal inflammation and administration of catalase prevented the anti-inflammatory actions of SOD (data not shown). Likewise, similar results were obtained in an allergic pleurisy model (Supplementary Figures 2B and C).

gp91 ${ }^{\text {phox }}$ deficiency extends the duration of allergic inflammation. Because treatment with $\mathrm{H}_{2} \mathrm{O}_{2}$ resolved eosinophilic inflammation, a series of experiments were then performed in gp $91^{\text {phox }-1-}$ mice, which lack the ability to assemble the NADPH oxidase and have decreased capacity to generate ROS. ${ }^{18}$ ROS production in gp $91^{\text {phox-l- mice was }}$ significantly lower when compared to wild-type mice (Figure 2a). In these mice, natural resolution of eosinophilic inflammation, which usually is complete within $72 \mathrm{~h}$ in WT mice, was not observed even at $96 \mathrm{~h}$ after antigen challenge (Figure 2b). Likewise, intranasal treatment with apocynin (an inhibitor of NADPH oxidase) at a dose of $10 \mathrm{mg} / \mathrm{kg}$ prevented natural resolution of eosinophilic inflammation at 72 and $96 \mathrm{~h}$ after challenge (Figure $2 b$ ).

The histopathological analysis of lung sections showed that within $72 \mathrm{~h}$ the inflammation was present only in focal segments in wild-type mice (WT) and lung tissue was mostly preserved (Figure 2d). In contrast, there was much infiltration of inflammatory cells and derangement of tissue architecture at $72 \mathrm{~h}$ in $\mathrm{gp} 91^{\text {phox-/- }}$ mice exposed to antigen when compared with the control group (PBS, Figures $2 d$ and e).

$\mathrm{H}_{2} \mathrm{O}_{2}$ treatment induced caspase-dependent apoptosis of eosinophils. Considering that the generation of endogenous $\mathrm{H}_{2} \mathrm{O}_{2}$ (via treatment with SOD) and administration of $\mathrm{H}_{2} \mathrm{O}_{2}$ reduced the number of eosinophils, we investigated whether death of eosinophils via apoptosis could underlie the resolution of eosinophilic inflammation. Indeed, there was significant increase in the number of apoptotic eosinophils as observed morphologically in mice treated with either SOD 
a

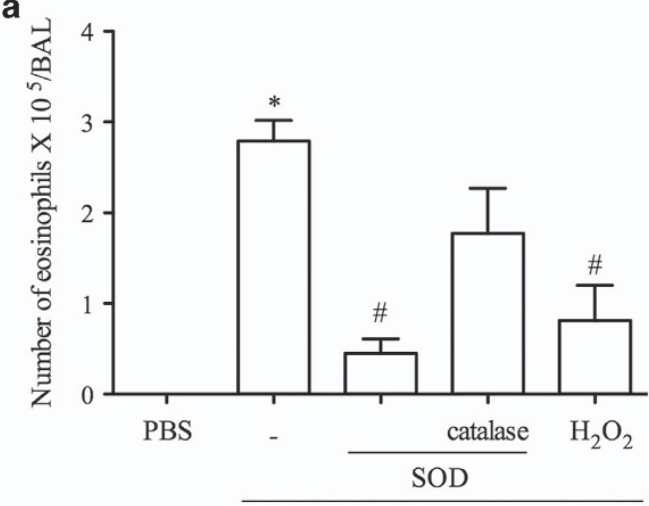

48 hours after OVA challenge b

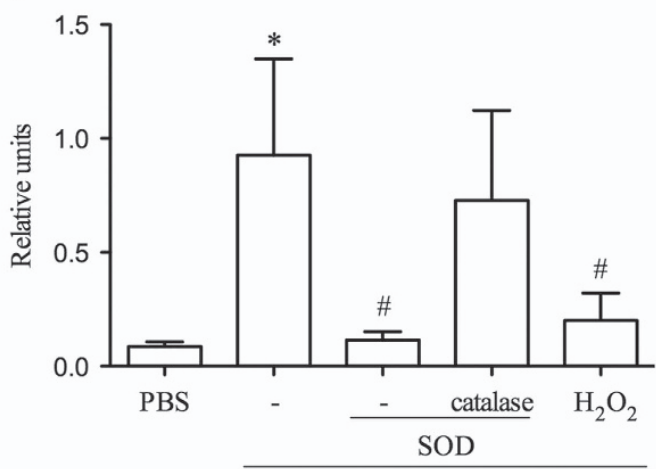

48 hours after OVA challenge

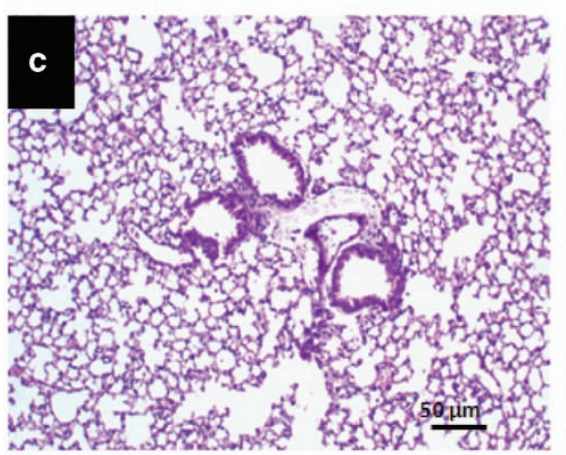

PBS

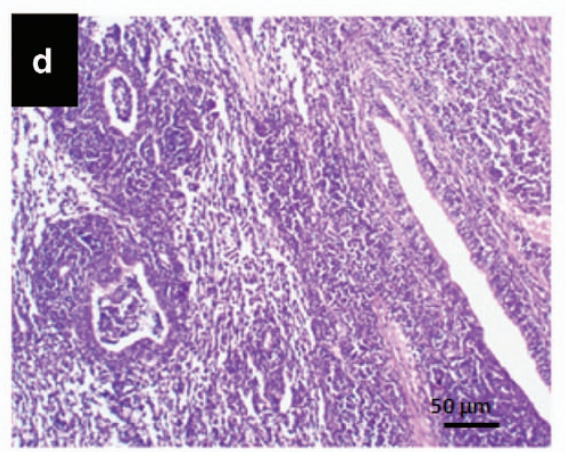

WT

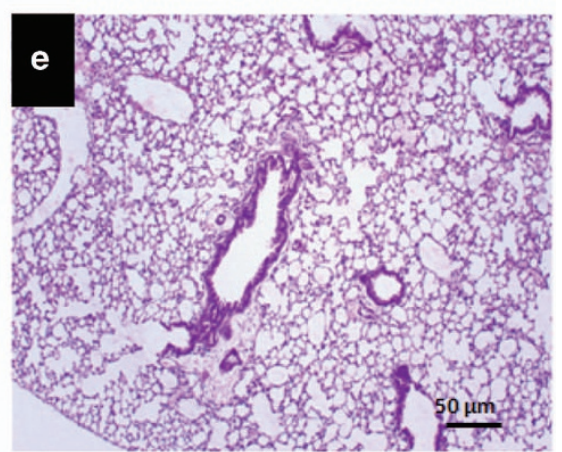

$\mathrm{H}_{2} \mathrm{O}_{2}$

48h after OVA challenge

Figure $1 \quad \mathrm{H}_{2} \mathrm{O}_{2}$ promotes resolution of inflammation in a mouse model of asthma. Number of eosinophils after administration of $\mathrm{SOD}(0.3 \mathrm{mg} / \mathrm{kg}), \mathrm{SOD}+\mathrm{catalase}(1.2 \mathrm{mg} / \mathrm{kg})$, $\mathrm{H}_{2} \mathrm{O}_{2}(0.5 \mathrm{M})$ or vehicle (30 $\mu$ l PBS) (a). Eosinophil peroxidase (b). Photomicrographs of lung sections - PBS (c), asthma (d) $\mathrm{H}_{2} \mathrm{O}_{2}(\mathbf{e}) \mathrm{H} \& \mathrm{E}$. $100 \times$. Scale $50 \mu \mathrm{m}$. Data represent mean \pm S.E.M. $(n=5)$. ${ }^{*} P<0.05$ versus control mice. ${ }^{\#} P<0.05$ versus OVA mice

or $\mathrm{H}_{2} \mathrm{O}_{2}$ (Figures 3a and $\mathrm{d}-\mathrm{g}$ and Supplementary Figure 2D) and demonstrated by flow cytometric analysis (Figure 3b). In mice treated with $\mathrm{H}_{2} \mathrm{O}_{2}$, there was an increase in expression of annexin V-FITC+ in CCR3+ cells at $2 \mathrm{~h}$ after treatment (Figure $3 b$ ). These data were confirmed by increased staining for cleaved caspase-3 in eosinophils, but not in mononuclear cells, in BAL from ova-challenged mice treated with $\mathrm{H}_{2} \mathrm{O}_{2}$ (Supplementary Figure 3 ). In contrast, $T$ cells were not affected by $\mathrm{H}_{2} \mathrm{O}_{2}$ (\% of cells CD3+/AnnX-V+: PBS: $0.69 \pm 0.24 ; \quad$ OVA: $\quad 0.74 \pm 0.18, \quad$ OVA $+\mathrm{H}_{2} \mathrm{O}_{2}: \quad 1.04 \pm 0.22$ $P>0.05, n=6$ ), suggesting that $\mathrm{H}_{2} \mathrm{O}_{2}$ treatment affected eosinophils more specifically. Treatment of animals with zVAD-fmk, a pan-caspase inhibitor, reversed the proresolution actions of $\mathrm{H}_{2} \mathrm{O}_{2}$, demonstrating the caspase dependency of the resolution of eosinophilic inflammation (Figure 3c).

$\mathrm{H}_{2} \mathrm{O}_{2}$ induces concentration-dependent apoptosis of an eosinophilic cell line in vitro. Next, we evaluated whether $\mathrm{H}_{2} \mathrm{O}_{2}$ could induce directly the apoptosis of a human eosinophil cell line, Eol-1. This cell line has been extensively used as a model of eosinophil function, including chemotaxis, mediator release and apoptosis induction. ${ }^{26,27}$ Eol-1 cells were incubated for a 4-h period with increasing concentrations of $0.3,1.0$ and $3.0 \mathrm{mM} \mathrm{H}_{2} \mathrm{O}_{2}$. Annexin-V-positive cells were considered apoptotic cells and annexin-V/PI dual-positive cells were considered late apoptotic/secondarily necrotic cells. $\mathrm{H}_{2} \mathrm{O}_{2}$ markedly increased apoptosis of Eol-1 cells in a concentration-dependent manner (Figure 4a). In order to confirm that Eol-1 cells undergo apoptosis following incubation with $\mathrm{H}_{2} \mathrm{O}_{2}$, Eol-1 was coincubated with $\mathrm{H}_{2} \mathrm{O}_{2}$ and Q-VD-OPh, a highly effective pan-caspase inhibitor. Coincubation of Eol-1 with Q-VD-OPh abrogated the ability of $\mathrm{H}_{2} \mathrm{O}_{2}$ to induce apoptosis (Figure 4b). To demonstrate further the role of caspase-3 in Eol-1 apoptosis induced by $\mathrm{H}_{2} \mathrm{O}_{2}$, we performed western blot analysis to investigate expression of cleaved caspase- 3 on lysates from Eol- 1 cells $4 \mathrm{~h}$ after stimulation with different concentrations of $\mathrm{H}_{2} \mathrm{O}_{2} \cdot \mathrm{H}_{2} \mathrm{O}_{2}$ caused caspase-3 cleavage when compared with cells treated with media alone (Figure 4c). Apoptosis was also assessed morphologically using light microscopy after cytocentrifugation and staining with Diff-Quick. We observed that apoptotic Eol-1 cells exhibited nuclear condensation and cellular shrinkage, confirming flow cytometric data (data not shown).

$\mathrm{H}_{2} \mathrm{O}_{2}$ reduces airway hyperreactivity to methacholine. Airway hyperreactivity (AHR) has been studied in a wellestablished murine model of asthma. ${ }^{28}$ In this model, the time course of the eosinophilic infiltrate was similar to that 

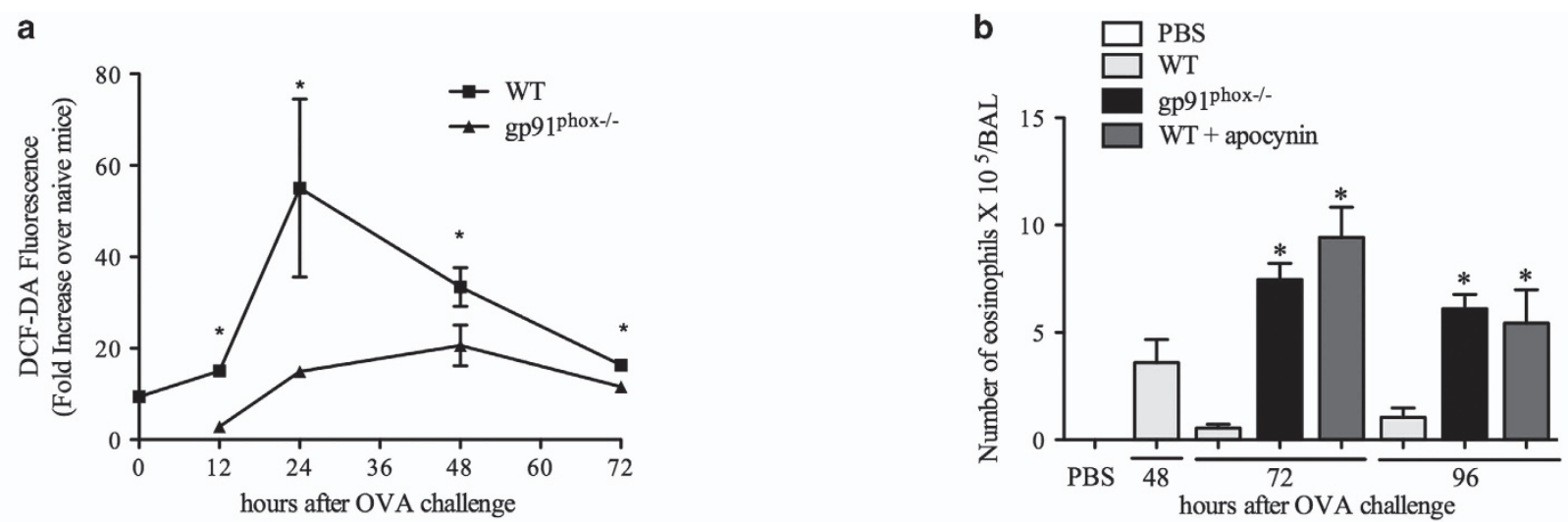

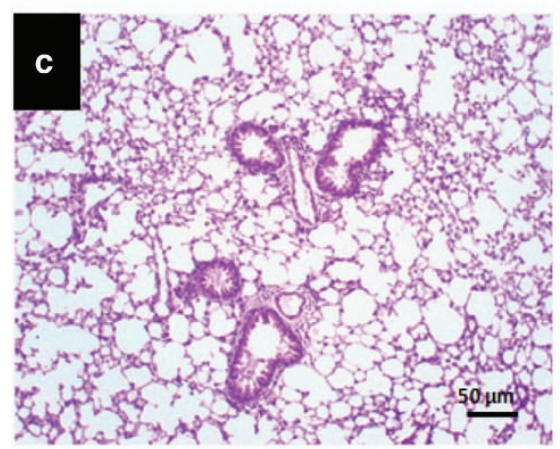

PBS

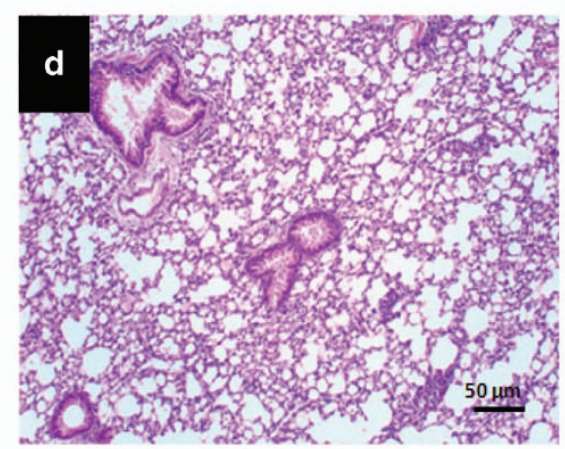

WT

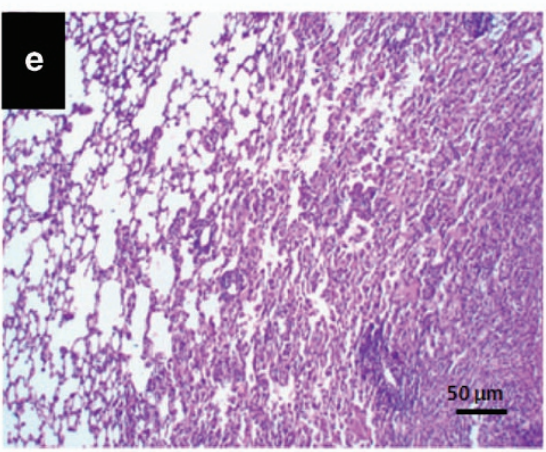

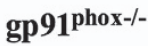

72h after OVA challenge

Figure 2 ROS derived from NADPH oxidase is necessary for inflammation resolution. ROS production in WTor gp91 phox $-1-$ mice (a). Eosinophils 72 and $96 \mathrm{~h}$ after OVA in gp9 $1^{\text {phox }-I-}$ mice and after apocynin treatment (b). Eosinophil peroxidase (c). Lung sections of PBS (d), WT (e) gp91 phox-I- (f). H\&E. $100 x$. Scale $50 \mu$ m. Data represent mean \pm S.E.M. $(n=5) .{ }^{*} P<0.05$ versus control group

observed in our previous experiments (see Supplementary Figure 4 and compare with Supplementary Figure 1). Akin to experiments described previously, delayed treatment with $\mathrm{H}_{2} \mathrm{O}_{2}$ resolved the eosinophilic infiltrate in the BAL at $48 \mathrm{~h}$ after antigen challenge (Figures $5 \mathrm{a}$ and $\mathrm{d}$ ) when compared with the control group (PBS, Figures $5 a$ and $b$ ). In these mice, AHR was assessed by measuring airway resistance (RI) and lung elastance parameters in mechanically ventilated animals. As shown in Figure 6, antigen challenge with OVA exacerbated airway resistance and elastance of the lungs in response to inhaled methacholine $(3-81 \mathrm{mg} / \mathrm{ml})$, as compared with the control group challenged with PBS. Treatment with $\mathrm{H}_{2} \mathrm{O}_{2}$ reduced $A H R$, as seen by decreased airway resistance and elastance (Figure 6).

Effect of $\mathrm{H}_{2} \mathrm{O}_{2}$ administration on mucus deposition and lung remodeling. To evaluate mucus production, sections of lung tissue were stained with periodic acid-Schiff. The analysis of airway mucins demonstrated significant metaplasia of goblet cells and mucus accumulation at $48 \mathrm{~h}$ after the last OVA challenge in actively sensitized mice (Figures $5 \mathrm{e}$ and g) in comparison with the control group (PBS) (Figure 5f). Treatment with $\mathrm{H}_{2} \mathrm{O}_{2}$ reduced OVA-induced mucus accumulation and the percentage of mucus producing cells to values similar to those observed in nonallergic controls (Figures $5 e, f$ and $h$ ). The lung sections stained with Gomori trichrome demonstrated that OVA mice had increased peribronchiolar matrix deposition as compared with the PBS mice (Figures 5i-I). Quantitative analyses demonstrated that delayed treatment with $\mathrm{H}_{2} \mathrm{O}_{2}$ prevented extracellular matrix deposition in challenged mice (Figures $5 \mathrm{i}$ and $\mathrm{I}$ ). Furthermore, $\mathrm{H}_{2} \mathrm{O}_{2}$ treatment decreased concentrations of CCL11, CCL24, IL-4, IL-5 and TNF- $a$ that were measured at $48 \mathrm{~h}$ after antigen challenge (Table 1 ).

\section{Discussion}

There is strong evidence indicating an important role for eosinophils in the pathogenesis of allergic diseases through the release of a variety of inflammatory mediators, including MBP, EPO and cytokines. ${ }^{1}$ Here, we evaluated the role of endogenous and effects of exogenous administration of $\mathrm{H}_{2} \mathrm{O}_{2}$ in the context of resolution of allergic inflammation. The results presented here can be summarized as follows: (i) treatment with $\mathrm{H}_{2} \mathrm{O}_{2}$ or strategies that enhanced $\mathrm{H}_{2} \mathrm{O}_{2}$ reduced eosinophil accumulation in the BAL and lung tissue; (ii) $\mathrm{H}_{2} \mathrm{O}_{2}$ promoted resolution of inflammation by inducing caspasedependent apoptosis of eosinophils in vivo; (iii) $\mathrm{H}_{2} \mathrm{O}_{2}$ also induced caspase-dependent apoptosis of a human eosinophilic cell line in vitro. (iv) $\mathrm{H}_{2} \mathrm{O}_{2}$ derived from NADPH oxidase was necessary for natural resolution of allergic inflammation; (v) finally, treatment with $\mathrm{H}_{2} \mathrm{O}_{2}$ decreased secretion of mucus, 
a

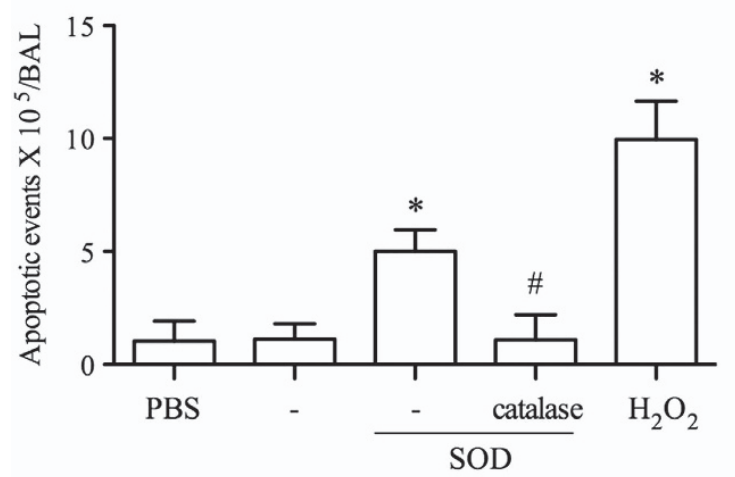

48 hours after OVA challenge

b

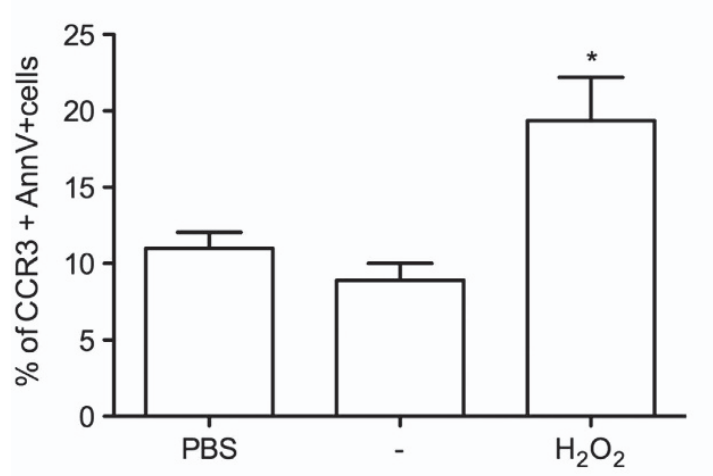

26 hours after OVA challenge

C

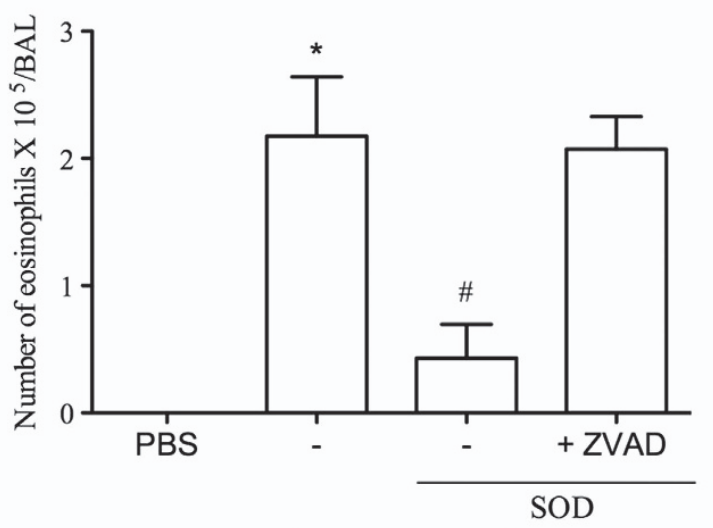

48 hours after OVA challenge
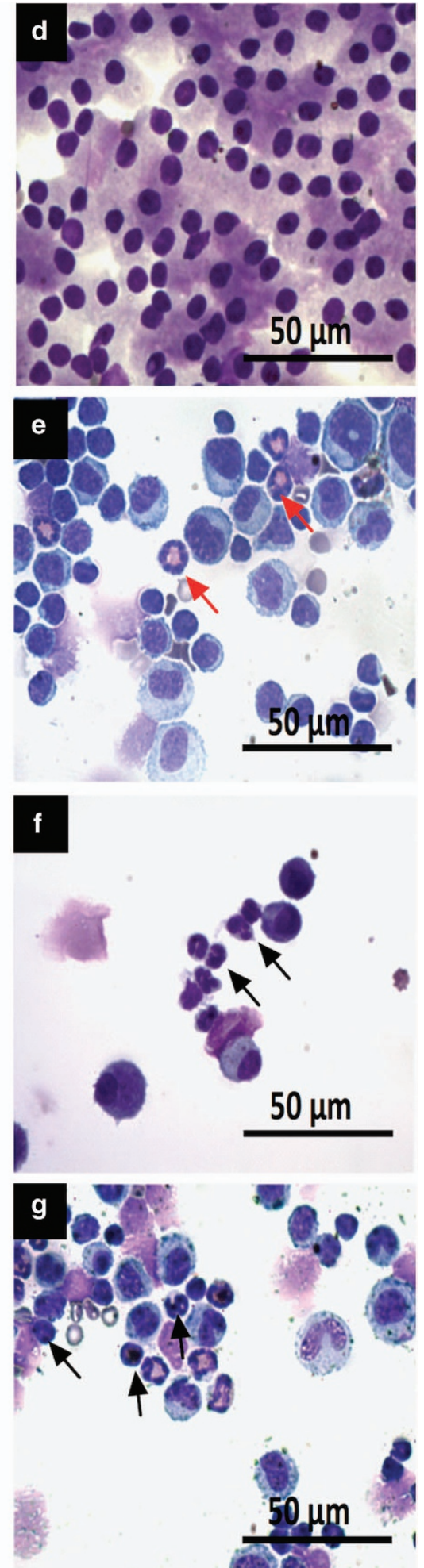

Figure $3 \quad \mathrm{H}_{2} \mathrm{O}_{2}$ induces apoptosis of eosinophils. $\mathrm{SOD}(0.3 \mathrm{mg} / \mathrm{kg})$, SOD+catalase $(1.2 \mathrm{mg} / \mathrm{kg}), \mathrm{H}_{2} \mathrm{O}_{2}(0.5 \mathrm{M})$ or vehicle $(30 \mu \mathrm{l}$ PBS) i.n. Apoptotic morphology (a) Cells expressing Annexin V-FITC+CCR3+ (b). Eosinophils after zVAD-fmk administration (1 mg/kg, i.p) (c). Cell types. Red arrow normal eosinophil. Black arrow: eosinophil with apoptotic morphology. PBS (d) asthma (e) $\mathrm{SOD}$ (f) $\mathrm{H}_{2} \mathrm{O}_{2}$ (g). $100 \times$ Scale: $50 \mu$ m. Data represent mean \pm S.E.M. $(n=5) .{ }^{*} P<0.05$ versus control mice. ${ }^{\#} P<0.05$ versus 0 VA mice

extracellular matrix deposition, inflammatory cytokine production and decreased AHR induced by antigen. Altogether, these results demonstrate a clear proresolving effect of $\mathrm{H}_{2} \mathrm{O}_{2}$ in allergic inflammation in vivo.
In our experiments, we have demonstrated that endogenous or exogenous $\mathrm{H}_{2} \mathrm{O}_{2}$ resolved eosinophilic inflammation in two different models of the allergic response. In the asthma model, this event correlated with increased number of 

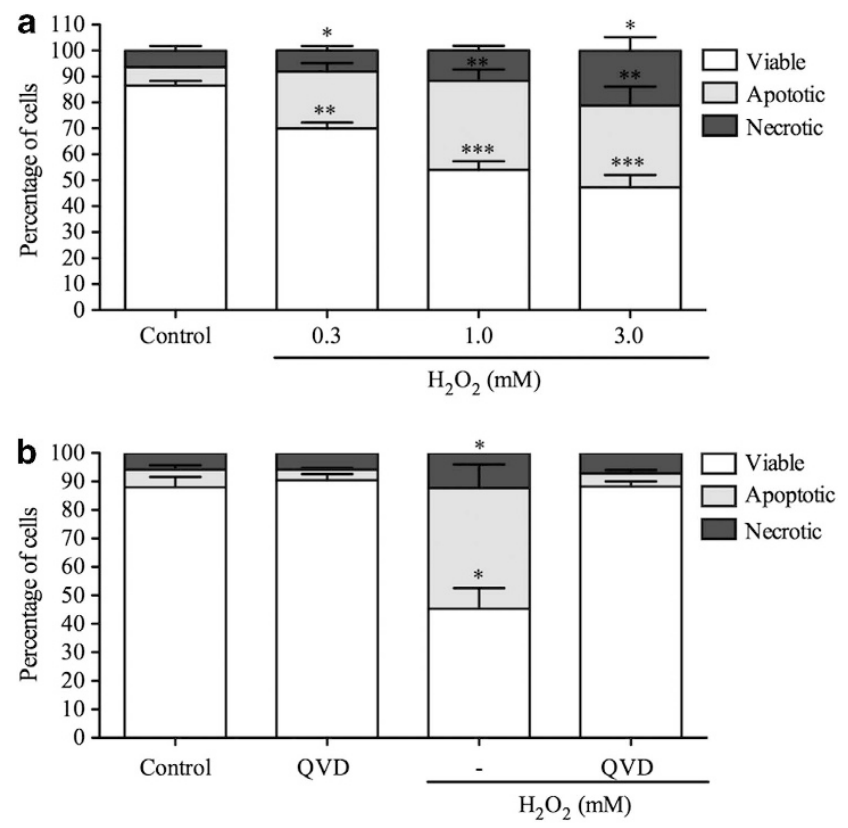

C

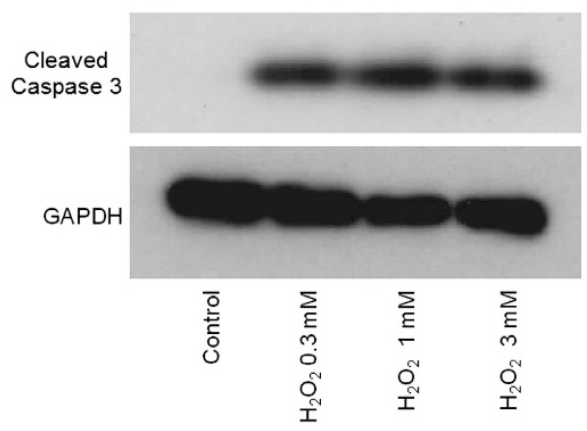

Figure $4 \quad \mathrm{H}_{2} \mathrm{O}_{2}$ induces concentration and caspase-dependent apoptosis in Eol-1 cells. Eol-1 cells with $\mathrm{H}_{2} \mathrm{O}_{2}(0.3 \mathrm{mM}-3.0 \mathrm{mM})$ (a) or $\mathrm{H}_{2} \mathrm{O}_{2}(1 \mathrm{mM})$ and Q-VD-OPh $(10 \mu \mathrm{M})(\mathbf{b})$. Western blotting for cleaved caspase-3 $(17 / 19 \mathrm{kDa})$ and GAPDH $(37 \mathrm{kDa})(\mathbf{c})$. Data represent mean \pm S.E.M. $n=3$. ${ }^{*} P<0.05,{ }^{* *} P<0.01$, ${ }^{* \star *} P<0.001$. Western blots representative on three experiments

apoptotic eosinophils. This is similar to the role of $\mathrm{H}_{2} \mathrm{O}_{2}$ in a model of arthritis, in which $\mathrm{H}_{2} \mathrm{O}_{2}$ limits inflammation associated with induction of caspase-dependent apoptosis of neutrophils. ${ }^{18}$ In fact, blockade of caspases with a pancaspase inhibitor, zVAD-fmk, prevented apoptosis and the resolution of eosinophilic inflammation induced by $\mathrm{H}_{2} \mathrm{O}_{2}$ consistent with our previous studies on neutrophils. $\mathrm{H}_{2} \mathrm{O}_{2}$ has been shown to induce apoptosis in culture of different cell types including human hepatocyte cells, ${ }^{29}$ epithelial cells, ${ }^{30}$ endothelial cells ${ }^{31}$ and myocytes. ${ }^{32}$ Here, we demonstrate that $\mathrm{H}_{2} \mathrm{O}_{2}$ also induced apoptosis of a human eosinophilic cell line, as by assessed by flow cytometry, light microscopy and cleavage of caspase-3 assessed by western blotting. The experiments using Eol-1 cells suggest that this pathway may be relevant in humans and clearly deserve further investigation in human disease. Indeed, ROS have been reported to increase apoptosis of human eosinophils. ${ }^{33,34}$ Therefore, our evidence suggests that resolution of eosinophilic inflammation by endogenous or exogenous $\mathrm{H}_{2} \mathrm{O}_{2}$ is due to the capacity of this molecule to induce caspase-dependent apoptosis of eosinophils.

Results in gp91phox-deficient mice showed that influx was not altered but persistency of eosinophils in tissues was greatly prolonged. Moreover, the intranasal treatment with an inhibitor of NADPH oxidase delayed the resolution of inflammatory response. It has been reported that in conditions of oxidative stress, the NADPH oxidase complex catalyzes electron transfer from NADPH to molecular oxygen and generates superoxide anions $\left(\mathrm{O}_{2}^{-}\right)$. The superoxide dismutase (SOD) degrades $\mathrm{O}_{2}^{-}$in $\mathrm{H}_{2} \mathrm{O}$ and produces $\mathrm{H}_{2} \mathrm{O}_{2} \cdot{ }^{23}$ Our work is the first to describe the importance of the oxidative pathway involving NADPH oxidase to resolve eosinophilic response. This is consistent with other studies in mice, which showed that $\mathrm{gp} 91^{\text {phox-I- }}$ mice had delayed resolution of neutrophilic inflammation and this process was reversed by administration of exogenous $\mathrm{H}_{2} \mathrm{O}_{2}$ in a model of antigeninduced arthritis. ${ }^{18}$ These data support the concept that ROS, which are generated by the phagocytic NADPH oxidase and commonly considered harmful mediators of acute inflammation, have a role in limiting inflammation and may be pivotal in resolving acute inflammation. ${ }^{35}$ Indeed, our results show that $\mathrm{H}_{2} \mathrm{O}_{2}$ not only induces resolution of inflammation, but it is also relevant in the context of the natural resolution of eosinophilic inflammation. Recent data show that administration of SOD accelerates resolution of inflammation associated to antigeninduced arthritis resulting in increased number of apoptotic neutrophils. This coincided with activation of caspase-3 and increased Bax expression in neutrophils recovered from the articular cavity. ${ }^{18}$ We also investigated whether reactive nitrogen species (RNS) participate in the resolution of the inflammatory response in the model of allergic asthma. It was observed that in the absence of NO production by iNOS there was no change in the resolution of allergic inflammation (Supplementary Figure 5). RNS such as NO are involved in the inflammatory process in the airways of asthmatic patients. $\mathrm{NO}$ has also been shown to be involved in the regulation of apoptosis: it can prevent or induce apoptosis depending upon the cell type and the concentration in which it is produced. ${ }^{36-40}$ The data suggest that RNS are not essential for resolution of allergic inflammation.

Our results showed that in addition to resolving eosinophilic inflammation, treatment with $\mathrm{H}_{2} \mathrm{O}_{2}$ had major physiological consequences in a model of allergic asthma. Indeed, treatment with $\mathrm{H}_{2} \mathrm{O}_{2}$ greatly reduced eosinophil accumulation, changes in airway reactivity, remodeling and mucus deposition induced by antigen challenge of immunized mice. Cytokines, including IL-4, IL-5 and TNF- $a$, and chemokines (CCL11 and CCL24) are thought to be involved in eosinophil accumulation and linked to pathophysiology of allergic disease. $^{41-44}$ There is also evidence that IL-5 and TNF-a promote eosinophil survival in vitro. ${ }^{45-47}$ In addition, CCL11 and CCL24 are important for eosinophil recruitment from the blood to the parenchyma and then into the airway. ${ }^{48}$ However, the evidence that antibody or drugs targeting these cytokines or chemokine induce resolution of eosinophilic inflammation in vivo is scanty. In addition, IL-4, IL-5 and TNF-a are essential for the development of AHR, mucus production and fibrosis in asthma. ${ }^{49-51}$ Similarly, chemokines, such as CCL11 and CCL24, may also contribute to AHR and fibrogenesis in 
a
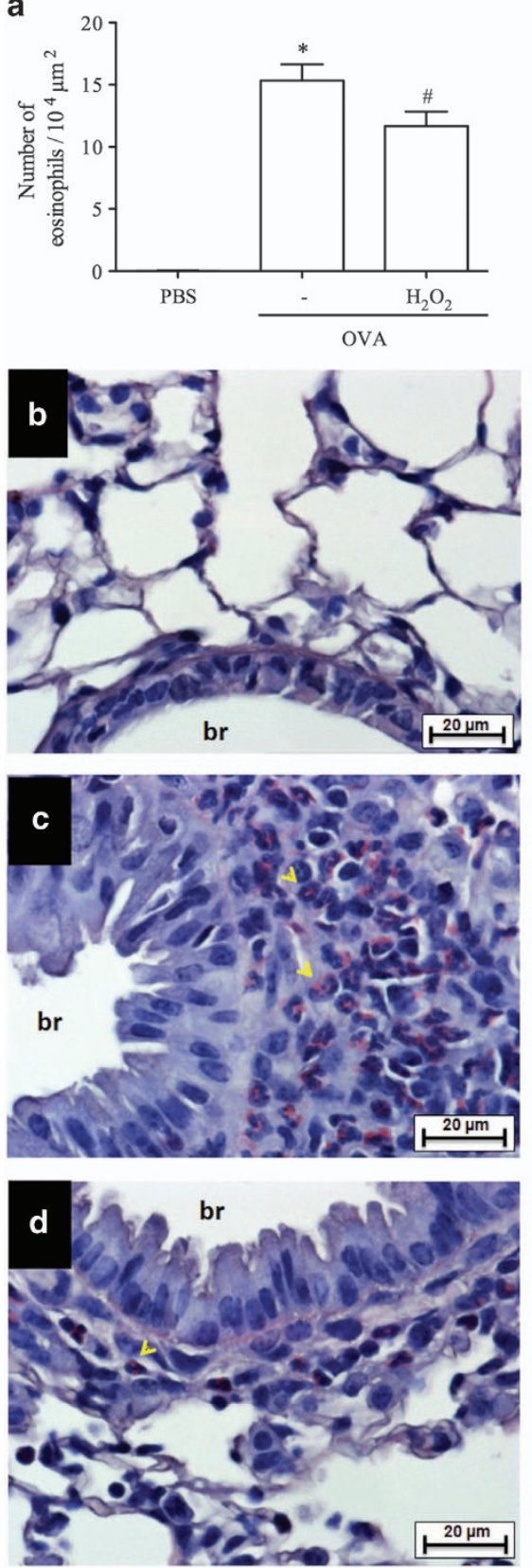
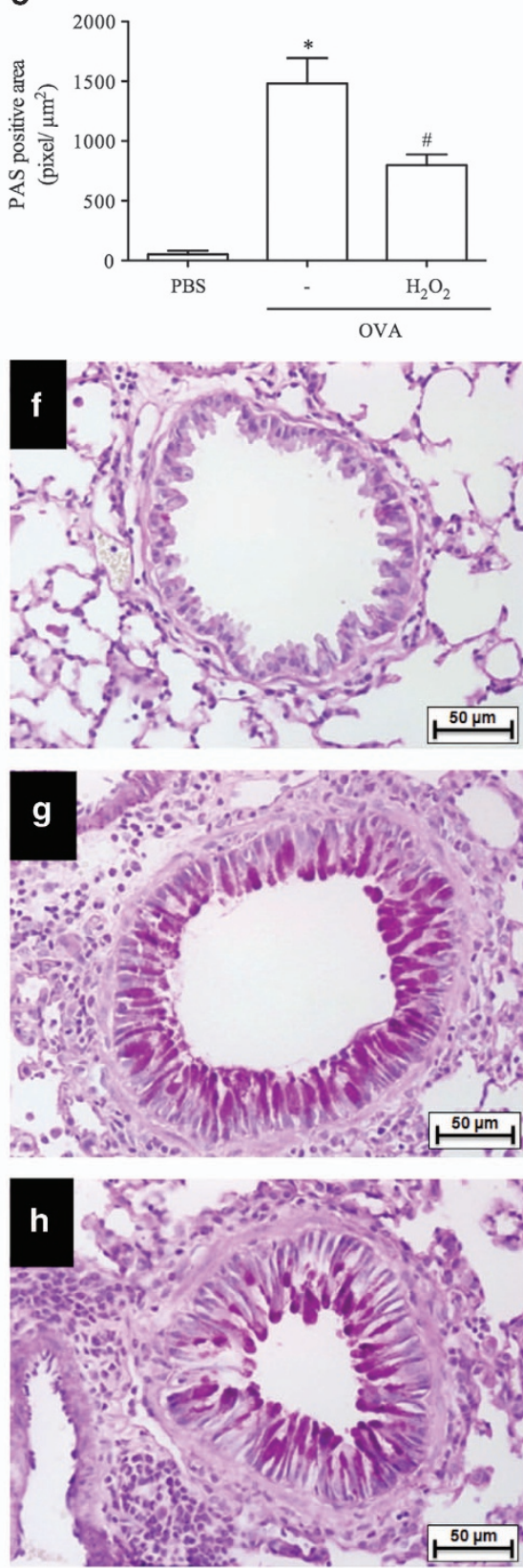

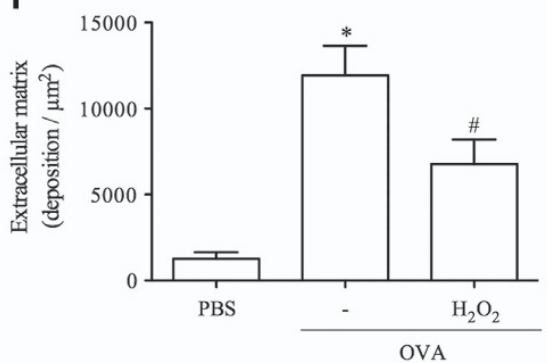

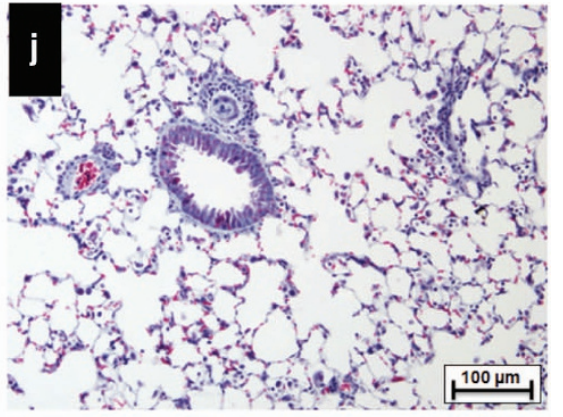
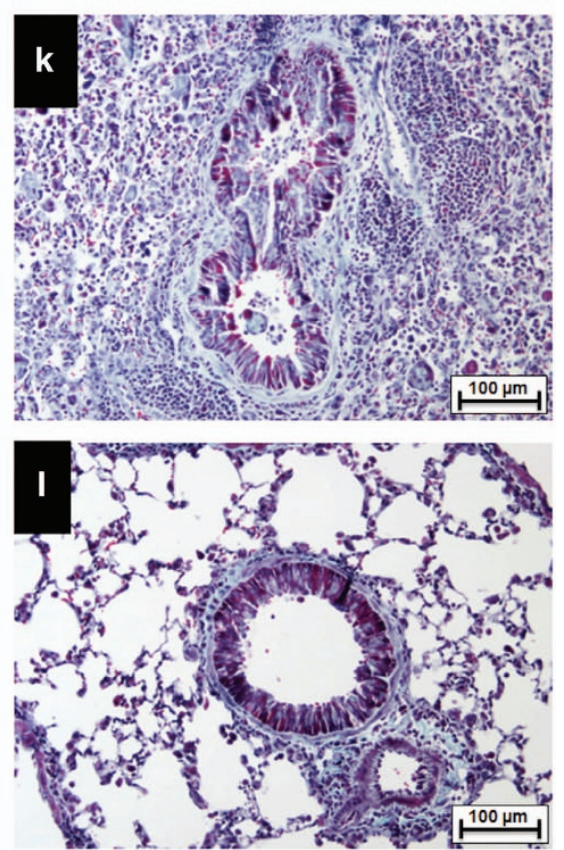

Figure 5 Effect of $\mathrm{H}_{2} \mathrm{O}_{2}$ on lung remodeling and mucus deposition. Leukocyte infiltrate around the bronchial region of the lung sections stained with hematoxylin and eosin (H\&E) or Sirius Red (pH 10.2) (a-d). Mucus production from airway stained with hematoxylin and Periodic acid-Schiff (PAS) (e-h). 400x. Peribronchial fibrosis stained with hematoxylin and eosin and a combination of Gomori trichrome (i-I). $200 \times$ x. ${ }^{*} P<00.5$ versus control mice. ${ }^{\sharp} P<0.05$ versus OVA mice

animal models of asthma. ${ }^{42,48}$ In our studies, there was a marked decrease in levels of these cytokines, which accompanied the resolution of the eosinophil numbers. Resolution of inflammation is known to exert potent anti-inflammatory effects and decrease of production of proinflammatory cytokines, ${ }^{52,53}$ suggesting that decreased levels of TNF, IL-5, $\mathrm{IL}-4$ and chemokines are likely a consequence of the antiinflammatory action of the resolution process. Alternatively, it is also possible that ROS induced a primary decrease of cytokines that could have then accounted for eosinophil apoptosis and in the resolution of eosinophilic inflammation.
The latter possibility is more difficult to ascertain in the in vivo situation and clearly more studies are needed to convincingly show that blockade of cytokines alter survival of eosinophils in vivo, as demonstrated in vitro. Whatever the mechanism, direct effect on eosinophils (shown here) or an indirect action via decrease on survival factors, our data clearly demonstrate the proresolving effects of $\mathrm{H}_{2} \mathrm{O}_{2}$ in the context of eosinophilic inflammation. Taken together our findings show that exogenous or endogenous generation of $\mathrm{H}_{2} \mathrm{O}_{2}$ resolve allergic inflammation by inducing eosinophil apoptosis in a caspasedependent manner. Induction of eosinophil apoptosis by $\mathrm{H}_{2} \mathrm{O}_{2}$ 

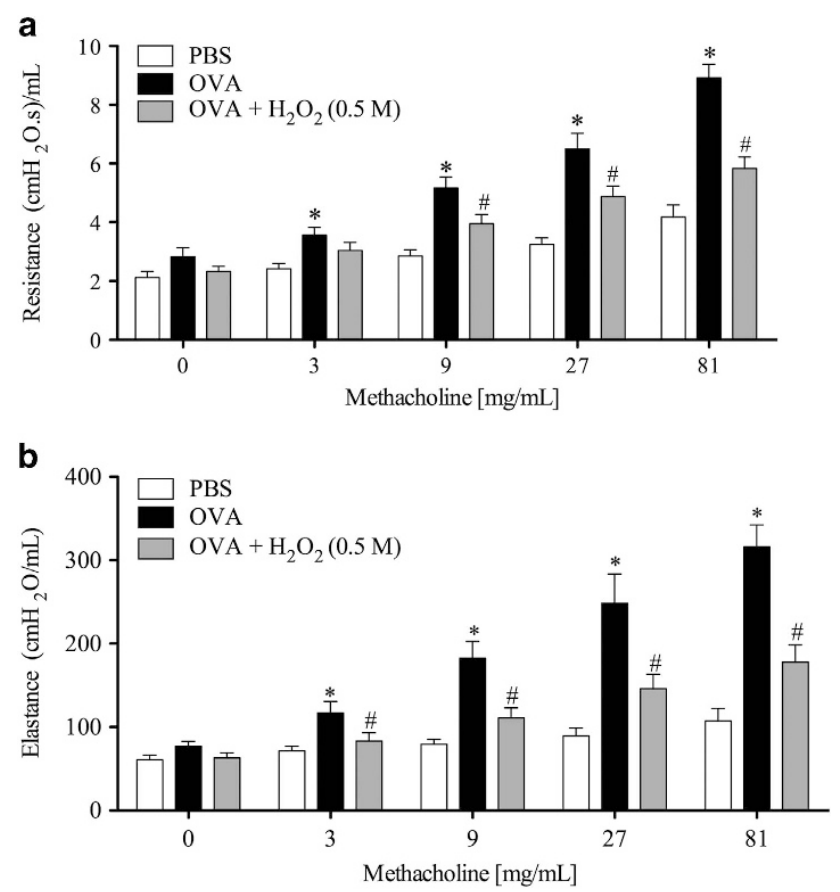

Figure 6 Airway resistance and dynamic elastance after increasing methacholine doses. $\mathrm{H}_{2} \mathrm{O}_{2}(0.5 \mathrm{M})$ or vehicle ( $30 \mu \mathrm{l}$ PBS) was administered i.n. instillation $24 \mathrm{~h}$ after asthma induction. Airway resistance (a) and elastance (b) was measured in response to increasing doses of methacholine $(3,9,27,81)$. Data represent mean \pm S.E.M. $(n=10)$. ${ }^{*} P<0.05$ versus vehicle group. ${ }^{\#} P<0.05$ versus OVA mice

Table 1 Levels of cytokines in lung $(\mathrm{pg} / \mathrm{ml})$

\begin{tabular}{lccc}
\hline Cytokines & PBS & OVA & $\mathbf{H}_{\mathbf{2}} \mathbf{O}_{2}$ \\
\hline CCL11 & $743 \pm 152$ & $9109 \pm 5063^{\mathrm{a}}$ & $5845 \pm 2048^{\mathrm{b}}$ \\
CCL24 & $903 \pm 245$ & $11956 \pm 6304^{\mathrm{a}}$ & $6896 \pm 1143^{\mathrm{b}}$ \\
IL-4 & $110 \pm 32$ & $238 \pm 149^{\mathrm{a}}$ & $127 \pm 34^{\mathrm{b}}$ \\
IL-5 & $847 \pm 84$ & $1226 \pm 445^{\mathrm{a}}$ & $829 \pm 140^{\mathrm{b}}$ \\
TNF- $a$ & $182 \pm 41$ & $310 \pm 135^{\mathrm{a}}$ & $157 \pm 45^{\mathrm{b}}$ \\
\hline
\end{tabular}

Abbreviations: TNF- $a$, tumor necrosis factor alpha; IL-4, interleukin-4; IL-5, interleukin-5

aSignificantly different from the control group $(P<0.05)$

${ }^{\mathrm{b}} \mathrm{Significantly} \mathrm{different} \mathrm{from} \mathrm{the} \mathrm{vehicle} \mathrm{group}(P<0.05)$

decreases airway remodeling and dysfunction. These results have fundamental implications to the basic concept of inflammation resolution and may have therapeutic implications. Indeed, our results demonstrate that resolution of eosinophilic inflammation by $\mathrm{H}_{2} \mathrm{O}_{2}$ maintains tissue integrity and function. Restoration of tissue inflammation to homeostasis may reverse airway function and remodeling in patients, a tenet that may be exploited for the development of novel therapies for the treatment of asthma.

\section{Materials and Methods}

Ethics statement. Male C57/BL6 and gp91 ${ }^{\text {phox }-1-}$ mice (Gene Cybb; ES Cell Line name CCE/EK.CE) ${ }^{54}$ (8-10 weeks) were bred and housed in a temperaturecontrolled room with free access to water and food. Animal Care and Use Committee and the study received prior approval from the local animal ethics committee (Animal Ethics Review Board - Comitê de Ética em Experimentação Animal-CETEA/Universidade Federal de Minas Gerais-UFMG (protocol number: 218/11).
Reagents and drugs. Superoxide dismutase (SOD) from bovine erythrocytes, catalase, $\mathrm{H}_{2} \mathrm{O}_{2}$, ovalbumin, Z-VAD-fmk, propidium iodide (PI) and 4,5-diaminofluoresceína-diacetato (DAF-2DA) were purchase from Sigma (St. Louis, MO, USA). Apo DETECT ANNEXIN-V-FITC KIT 2,7-diclorodihidrofluoresceína-diacetato (DCF-DA) and dihidrorodamine-123 (DHR-123) were purchase from Invitrogen (Life Technologies, São Paulo, Brazil). Antibodies were purchased from Santa Cruz Biotechnology (Santa Cruz, CA, USA). Q-VD-OPh (R\&D Systems, Minneapolis, MN, USA), annexin-V-FLUOS (Roche, Mannheim, Germany).

Eol-1 cell culture and apoptosis induction. Human eosinophilic cell line (Eol-1 cells) was maintained in RPMl-1640 medium (PAA) with 2\% FBS (Biosera), penicillin $(100 \mathrm{U} / \mathrm{ml})$ and streptomycin $(100 \mathrm{U} / \mathrm{ml})$ (PAA). Cells were aliquoted $\left(2 \times 10^{6} \mathrm{cell} / \mathrm{sl}\right)$ and incubated with $\mathrm{H}_{2} \mathrm{O}_{2}$ (Thermo Fisher Scientific, Waltham, MA, USA), Q-VD-OPh (R\&D Systems) or combinations of these either in 96-well-flat bottomed-plates (final volume of $150 \mu \mathrm{l}$ ) or in $2 \mathrm{ml}$ Eppendorf tubes (final volume of $500 \mu \mathrm{l}$ ) in a humidified, $37^{\circ} \mathrm{C}$ incubator at $5 \% \mathrm{CO}_{2}$ atmosphere or on a shaking, temperature-controlled heat block. Q-VD-OPh stock was initially dissolved in dimethyl sulphoxide (Sigma) then diluted in buffer yielding a final concentration of $0.2 \%$; a corresponding DMSO control of $0.2 \%$ was assessed as an appropriate vehicle control. Apoptosis was assessed by flow cytometry with a BD-LSR Fortessa (Becton Dickinson Biosciences, San Jose, CA, USA) using annexin-V-FLUOS (Roche) in combination with propidium iodide (PI) (Sigma) as described. ${ }^{55}$ Data were analyzed using Flowjo software (TreeStar, Ashland, OR, USA). Morphological apoptotic changes were assessed by light microscopy of DiffQuick stained cytocentrifuged cells. ${ }^{55}$

Western blotting. Cells at a concentration of $2 \times 10^{6} \mathrm{cell} / \mathrm{s} / \mathrm{ml}$ per condition were incubated with $\mathrm{H}_{2} \mathrm{O}_{2}$ (Thermo Fisher Scientific), Q-VD-OPh (R\&D Systems) or combinations of these at $37^{\circ} \mathrm{C}$ on a shaking heat block for $4 \mathrm{~h}$. Eol-1 cells were pelleted by centrifugation at $3000 \times g$ for $60 \mathrm{~s}$ and resuspended with whole-cell lysis buffer. Sample was incubated on ice for $10 \mathrm{~min}$ then NP-40 was added, briefly vortexed and centrifuged for $20 \mathrm{~min}$ at $3000 \times \mathrm{g}$. Supernatant was removed and the remaining cell pellet was resuspended in sample buffer before boiling at $95^{\circ} \mathrm{C}$ for $5 \mathrm{~min}$. Lysate were run on $12 \%$ precast gels (Thermo Fisher Scientific, Rockford, IL, USA) and transferred onto PVDF (Immobilon-P, Millipore, Herts, UK). Membranes were blocked for $1 \mathrm{~h}$ in $5 \%$ (wt/vol) dried milk/TBS/0.1\% Tween-20 before probing with antibodies to cleaved caspase-3 diluted 1:500 (Cell Signaling Technologies) at $4^{\circ} \mathrm{C}$ overnight or GAPDH diluted 1:20000 (Sigma-Aldrich, St. Louis, MO, USA) $1 \mathrm{~h}$ at room temperature. Following $3 \times 5$ min washes in TBS/0.1\%Tween-20, the blots were incubated with HRP-conjugated secondary antibody (Dako, Glostrup, Denmark) diluted $1: 2500$ for $1 \mathrm{~h}$ at room temperature before incubation with ECL (GE Healthcare, Bucks, UK) exposure to BioMax MS-1 X-ray-sensitive film, and processing (X-Ograph Imaging Systems, Wilts, UK).

Induction of asthma. All mice were sensitized intraperitoneally (i.p.) with $100 \mu \mathrm{g}$ of OVA (albumin from chicken egg white - A5503, Sigma-Aldrich) in $2 \%$ alum (aluminum hydroxide gel adjuvant; Brenntag) on day 0 , then challenged intranasally (i.n.) on days $8-10$ with $10 \mu \mathrm{g}$ of OVA or PBS ${ }^{56}$ The treatments with apocynin, SOD, $\mathrm{H}_{2} \mathrm{O}_{2}$ and catalase were performed i.n. and the ZVAD-fmk (Tocris Bioscience) was administered i.p.

Induction of pleurisy. Mice were immunized with OVA adsorbed to aluminum hydroxide gel as described. ${ }^{52}$ Briefly, mice were injected subcutaneously (s.c.) on days 1 and 7 with $0.2 \mathrm{ml}$ of a solution containing $100 \mathrm{mg}$ of OVA and $70 \mathrm{mg}$ of aluminum hydroxide. Sensitized mice were then challenged with OVA (1 mg/cavity, in a total volume of $100 \mathrm{ml}$ intrapleurally, i.pl) or PBS. Cells present in the pleural cavity were collected at different times by washing the cavity with $2 \mathrm{ml} \mathrm{PBS}$ and total cell counts performed in a modified Neubauer chamber using Turk's stain. Differential cell counts were performed on cytocentrifuge preparations (Shandon Cytospin III), stained with May-Grünwald-Giemsa using standard morphological criteria to identify cell types. The results are presented as the number of cells/cavity.

BAL analysis. BAL was performed to obtain leukocytes present in the alveolar space. Mice were killed by anesthetic overdose and the trachea of each animal was exposed and cannulated with a polypropylene catheter of $1.7 \mathrm{~mm}$. Airways were washed with $2 \mathrm{ml}$ of ice-cold PBS. Total cell counts were performed in a modified Neubauer chamber using Turk's stain. Differential cell counts were performed on cytocentrifuge preparations (Shandon Cytospin III), stained with May-GrünwaldGiemsa using standard morphological criteria to identify cell types. The results are 
presented as the number of cells/BAL. In a separated set of experiments, apoptotic cells were morphologically identified in cytocentrifuged slides, which were also positively stained for cleaved caspase-3 (Alexa Fluor 488 rabbit anti-mouse cleaved caspase-3; Cell Signaling; 1:50). Fluorescence intensity was measured offline using Volocity software 6.3 (Perkin-Elmer, Waltham, MA, USA) and fluoresce profile was assessed using Image $\mathrm{J}(\mathrm{NIH}){ }^{57}$

Histological analysis. The lung was prepared as described. ${ }^{58}$ Briefly, lungs were removed $24 \mathrm{~h}$ after the last challenge and fixed in Milloning buffer solution (pH 7.4) with $4 \%$ paraformaldehyde. For analysis of leukocyte infiltrate around the bronchial region, the lung sections were stained with hematoxylin and eosin (H\&E) or were subjected to Sirius Red ( $\mathrm{pH}$ 10.2) staining (Llewellyn's Sirus Red Direct Red 80, CI 35780; Aldrich, Milwaukee, WI, USA). Results were expressed as leukocytes/ $10^{4} \mu \mathrm{m}^{2}$. Mucus production was analyzed from tissue sections stained with Harris hematoxylin stain and a combination of Periodic acid-Schiff (PAS) stain (Schiff's reagent, Merck, Rio de Janeiro, Brazil). Photomicrographs of airways obtained at $400 \times$ magnification were analyzed using the software Image-Pro Plus (Image-Pro Plus, 4.1; Media Cybernetics, Houston, TX, USA). Nine to twelve bronchial areas per lung were outlined and quantified. Results were expressed as PAS positive area $\left(\right.$ pixels $\left./ \mu \mathrm{m}^{2}\right)$. Peribronchial fibrosis was analyzed from tissue sections stained with hematoxylin and eosin stain and a combination of Gömöritrichrome stain (Trichrome Stain LG Solution; Sigma-Aldrich). Photomicrographs of airways obtained at $200 x$ magnification were analyzed using the software Image-Pro Plus. Eight to twelve peribronchial area per lung were outlined and quantified. ${ }^{59}$ Results were expressed as extracellular matrix deposition area $\left(\mu \mathrm{m}^{2}\right)$.

Assessment of leukocyte apoptosis. Apoptosis was assessed as described. ${ }^{52,60}$ Briefly, cells $\left(5 \times 10^{4}\right)$ collected $48 \mathrm{~h}$ after antigen challenge were cytocentrifuged, fixed and stained with May-Grunwald-Giemsa and counted using oil immersion microscopy ( $\times 100$ objective) to determine the proportion of cells with distinctive apoptotic morphology (cell shrinkage, chromatin condensation, nuclear fragmentation and maintenance of membrane integrity). Twenty-five fields were counted per slide and the results expressed as the mean \pm S.E.M. of number of apoptotic cells in 25 fields. Assessment of apoptosis was also performed by flow cytometry using commercial kit annexin-V-FITC (Invitrogen) following the instructions of the manufacturer in cells previously stained with the following Abs to extracellular markers for 30 min on ice: anti-mouse CCR3 mAb (BD Biosciences, San Jose, CA, USA) or anti-mouse mAb CD3 (BD Biosciences). Flow cytometry was performed using a FACS Canto flow cytometer (BD). At least $10^{4}$ events were recorded and analyzed using FlowJo software (FlowJo, LLC, Ashland, OR, USA). Results are expressed as cells undergoing early stage apoptosis quantified by staining with annexin-V but not PI.

ELISA analysis. Murine IL-4, IL-5, TNF- $\alpha$, CCL11 and CCL24 levels were measured in right lung tissue samples by means of ELISA technique using commercial DuoSet kits R\&D Systems following the instructions of the manufacturer. Results were expressed in levels of cytokines per lung $(\mathrm{pg} / \mathrm{ml})$.

Quantification of eosinophil accumulation in lung. Pulmonary EPO activity was determined to estimate eosinophil recruitment into the lung parenchyma as described. ${ }^{61}$ Absorbance was read in an ELISA reader (Expert Plus ASYS Hitech $\mathrm{GmbH}$, Eugenorf, Austria) at $492 \mathrm{~nm}$. Values are expressed in O.D.

Determination of the production of reactive oxygen species and nitrogen by fluorimetry. Leukocytes obtained from the BAL were incubated separately with the probes ' -7 ' dicloro-dihidrofluoesceínadiacetate (DCF-DA $20 \mathrm{uM}$ ), dihidrorodaminadiacetate 123 (DHR-123 $5 \mathrm{uM}$ ) of 4,5-diaminofluorescein (DAF-2DA $10 \mathrm{uM}$ ) for $30 \mathrm{~min}$ in an oven at $37^{\circ} \mathrm{C}$. This stage of the experiment was performed in the dark, because the markers are photosensitive. The reading of fluorescence was performed in a fluorescence spectrophotometer (Synergy 2, Biotek, Winooski, VT, USA) with wavelengths of excitation and emission of 488 and $515 \mathrm{~nm}$, respectively.

Invasive assessment of respiratory mechanics. Airway reactivity was assessed as a change in airway function after challenge with aerosolized methacholine in a FinePoint $\mathrm{R} / \mathrm{C}$ Buxco Platform. The parameters were measured as previously described. ${ }^{62}$ The analyses were performed $48 \mathrm{~h}$ after the last OVA challenge.

Statistical analysis. ANOVA followed by Student Newman-Keuls was applied to comparison of multiple groups. In order to test statistical significance between two groups we used the unpaired Student's t-test (GraphPad Software, San Diego, CA, USA). All in vitro experiments were performed at least three times with each experiment carried out in triplicate. All in vivo experiments included six mice per group. Data were expressed as the mean \pm S.E.M. Differences were considered significant at $P<0.05$.

\section{Conflict of Interest}

The authors declare no conflict of interest.

Acknowledgements. The research leading to these results has received funding from the European Community's Seventh Framework Programme (FP72007-2013, Timer consortium) under grant agreement $n^{\circ}$ HEALTH-F4-2011-281608, Conselho Nacional de Desenvolvimento Cientifico eTecnológico (CNPq, Brazil) and Fundação de Amparo à Pesquisa do Estado de Minas Gerais (FAPEMIG, Brazil).

1. Luna-Gomes T, Bozza PT, Bandeira-Melo C. Eosinophil recruitment and activation: the role of lipid mediators. Fronti Pharmacol 2013; 4: 27.

2. Rothenberg ME, Hogan SP. The eosinophil. Ann Rev Immunol 2006; 24: 147-174.

3. Holgate ST. The airway epithelium is central to the pathogenesis of asthma. Allergol Int 2008; 57: 1-10.

4. Felton JM, Lucas CD, Rossi AG, Dransfield I. Eosinophils in the lung - modulating apoptosis and efferocytosis in airway inflammation. Front Immunol 2014; 5: 302.

5. Kay AB. The role of T lymphocytes in asthma. Chem Immunol Allergy 2006; 91: 59-75.

6. Afshar R, Medoff BD, Luster AD. Allergic asthma: a tale of many T cells. Clin Exp Allergy 2008; 38: 1847-1857

7. Nouri-Aria KT, Durham SR. Regulatory T cells and allergic disease. Inflamm Allergy Drug Targets 2008; 7: 237-252.

8. Jacobsen EA, Helmers RA, Lee JJ, Lee NA. The expanding role(s) of eosinophils in health and disease. Blood 2012; 120: 3882-3890.

9. Fulkerson PC, Rothenberg ME. Targeting eosinophils in allergy, inflammation and beyond. Nat Rev Drug Discov 2013; 12: 117-129.

10. Wilson SJ, Rigden HM, Ward JA, Laviolette M, Jarjour NN, Djukanovic R. The relationship between eosinophilia and airway remodelling in mild asthma. Clin Exp Allergy 2013; 112: 1342-1350.

11. Nair P. Anti-interleukin-5 monoclonal antibody to treat severe eosinophilic asthma. N Eng J Med 2014; 371: 1249-1251.

12. Duncan CJA, Lawrie A, Blaylock MG, Douglas JG, Walsh GM. Reduced eosinophil apoptosis in induced sputum correlates with asthma severity. Eur Respir J 2003; 22: 484-490.

13. Walsh GM. Eosinophil apoptosis: Mechanisms and clinical relevance in asthmatic and allergic inflammation. Brit J Haematol 2000; 111: 61-67.

14. Vignola AM, Chanez P, Chiappara G, Siena L, Merendino A, Reina C et al. Evaluation of apoptosis of eosinophils, macrophages, and T lymphocytes in mucosal biopsy specimens of patients with asthma and chronic bronchitis. J Allergy Clin Immunol 1999; 103: 563-573.

15. Gautier EL, Ivanov S, Lesnik P, Randolph GJ. Local apoptosis mediates clearance of macrophages from resolving inflammation in mice. Blood 2013; 122: 2714-2722.

16. Walsh GM. Eosinophil apoptosis and clearance in asthma. J Cell Death 2013; 6: 17-25.

17. Alessandri AL, Duffin R, Leitch AE, Lucas CD, Sheldrake TA, Dorward DA et al. Induction of eosinophil apoptosis by the cyclin-dependent kinase inhibitor AT7519 promotes the resolution of eosinophil-dominant allergic inflammation. PloS One 2011; 6: e25683.

18. Lopes F, Coelho FM, Costa VV, Vieira EL, Sousa LP, Silva TA et al. Resolution of neutrophilic inflammation by $\mathrm{H} 2 \mathrm{O} 2$ in antigen-induced arthritis. Arthritis Rheum 2011; 63: 2651-2660.

19. Fialkow L, Wang Y, Downey GP. Reactive oxygen and nitrogen species as signaling molecules regulating neutrophil function. Free Radic Biol Med 2007; 42: 153-164.

20. Wartha F, Henriques-Normark B. ETosis: a novel cell death pathway. Sci Signal 2008; 1: pe25.

21. Sareila O, Kelkka T, Pizzolla A, Hultqvist M, Holmdahl R. NOX2 complex-derived ROS as immune regulators. Antioxid Redox Signal 2011; 15: 2197-2208.

22. Segal BH, Grimm MJ, Khan AN, Han W, Blackwell TS. Regulation of innate immunity by NADPH oxidase. Free Rad Biol Med 2012; 53: 72-80.

23. Gardiner GJ, Deffit SN, McLetchie S, Perez L, Walline CC, Blum JS. A Role for NADPH oxidase in antigen presentation. Front Immunol 2013; 4: 295.

24. Han W, Li H, Cai J, Gleaves LA, Polosukhin VV, Segal BH et al. NADPH oxidase limits lipopolysaccharide-induced lung inflammation and injury in mice through reduction-oxidation regulation of NF-kappaB activity. J Immunol 2013; 190: 4786-4794.

25. Stock P, Akbari O, Berry G, Freeman GJ, Dekruyff RH, Umetsu DT. Induction of T helper type 1-like regulatory cells that express Foxp3 and protect against airway hyper-reactivity. Nat Immunol 2004; 5: 1149-1156.

26. Noda H, Sakagami H, Kokubu F, Kurokawa M, Tokunaga $H$, Takeda $M$ et al. Induction of apoptosis in human eosinophilic leukemic cell line (EOL-1). Int Arch Allergy Immunol 1997; 114(Suppl 1): 84-88.

27. Mayumi M. EoL-1, a human eosinophilic cell line. Leuk Lymphoma 1992; 7: 243-250. 
28. Bezerra-Santos CR, Vieira-de-Abreu A, Vieira GC, Filho JR, Barbosa-Filho JM, Pires AL et al. Effectiveness of Cissampelos sympodialis and its isolated alkaloid warifteine in airway hyperreactivity and lung remodeling in a mouse model of asthma. Int Immunopharmacol 2012; 13: 148-155.

29. Kim SJ, Jung HJ, Hyun DH, Park EH, Kim YM, Lim CJ. Glutathione reductase plays an antiapoptotic role against oxidative stress in human hepatoma cells. Biochimie 2010; 92 927-932.

30. Hussain S, Thomassen LC, Ferecatu I, Borot MC, Andreau K, Martens JA et al. Carbon black and titanium dioxide nanoparticles elicit distinct apoptotic pathways in bronchial epithelial cells. Part Fibre Toxicol 2010; 7: 10.

31. Fang WT, Li HJ, Zhou LS. Protective effects of prostaglandin E1 on human umbilical vein endothelial cell injury induced by hydrogen peroxide. Acta Pharmacologica Sinica 2010; 31: 485-492.

32. Zhang L, Jiang $H$, Gao $X$, Zou $Y$, Liu M, Liang $Y$ et al. Heat shock transcription factor-1 inhibits $\mathrm{H} 2 \mathrm{O} 2$-induced apoptosis via down-regulation of reactive oxygen species in cardiac myocytes. Mol Cell Biochem 2011; 347: 21-28.

33. Kankaanranta H, Giembycz MA, Barnes PJ, Haddad el B, Saarelainen S, Zhang X et al. Hydrogen peroxide reverses IL-5 afforded eosinophil survival and promotes constitutive human eosinophil apoptosis. Int Arch Allergy Immunol 2002; 127: 73-78.

34. Wedi B, Straede J, Wieland B, Kapp A. Eosinophil apoptosis is mediated by stimulators of cellular oxidative metabolisms and inhibited by antioxidants: involvement of a thiol-sensitive redox regulation in eosinophil cell death. Blood 1999; 94: 2365-2373.

35. Deng J, Wang X, Qian F, Vogel S, Xiao L, Ranjan R et al. Protective role of reactive oxygen species in endotoxin-induced lung inflammation through modulation of $\mathrm{IL}-10$ expression $\mathrm{J}$ Immunol 2012; 188: 5734-5740.

36. Zhang X, Moilanen E, Lahti A, Hamalainen M, Giembycz MA et al. Regulation of eosinophil apoptosis by nitric oxide: Role of C-Jun-N-terminal kinase and signal transducer and activator of transcription 5. J Allergy Clin Immunol 2003; 112: 93-101.

37. Pontin J, Blaylock MG, Walsh GM, Turner SW. Sputum eosinophil apoptotic rate is positively correlated to exhaled nitric oxide in children. Pediatr Pulmonol 2008; 43: 1130-1134.

38. IImarinen-Salo $P$, Moilanen $E$, Kankaanranta $H$. Nitric oxide induces apoptosis in GM-CSFtreated eosinophils via caspase-6-dependent lamin and DNA fragmentation. Pulm Pharmacol Ther 2010; 23: 365-371.

39. IImarinen-Salo $P$, Moilanen E, Kinnula VL, Kankaanranta H. Nitric oxide-induced eosinophil apoptosis is dependent on mitochondrial permeability transition (mPT), JNK and oxidative stress: apoptosis is preceded but not mediated by early mPT-dependent JNK activation. Respir Res 2012; 13: 73.

40. Ilmarinen $\mathrm{P}$, Moilanen $\mathrm{E}$, Kankaanranta $\mathrm{H}$. Mitochondria in the center of human eosinophil apoptosis and survival. Int J Mol Sci 2014; 15: 3952-3969.

41. Matera MG, Calzetta L, Cazzola M. TNF-alpha inhibitors in asthma and COPD: we must not throw the baby out with the bath water. Pulm Pharmacol Ther 2010; 23: 121-128.

42. Yang M, Hogan SP, Mahalingam S, Pope SM, Zimmermann N, Fulkerson P et al. Eotaxin-2 and IL-5 cooperate in the lung to regulate IL-13 production and airway eosinophilia and hyperreactivity. J Allergy Clin Immunol 2003; 112: 935-943.

43. Klein A, Talvani A, Silva PM, Martins MA, Wells TN, Proudfoot A et al. Stem cell factorinduced leukotriene B4 production cooperates with eotaxin to mediate the recruitment of eosinophils during allergic pleurisy in mice. J Immunol 2001; 167: 524-531.

44. Kobayashi T, lijima K, Kita H. Marked airway eosinophilia prevents development of airway hyper-responsiveness during an allergic response in IL-5 transgenic mice. J Immunol 2003 170: $5756-5763$.

45. Rosenberg HF, Phipps S, Foster PS. Eosinophil trafficking in allergy and asthma. J Allergy Clin Immunol 2007; 119: 1303-1310.

46. Yamaguchi Y, Hayashi Y, Sugama Y, Miura Y, Kasahara T, Kitamura S et al. Highly purified murine interleukin 5 (IL-5) stimulates eosinophil function and prolongs in vitro survival. IL-5 as an eosinophil chemotactic factor. J Exp Med 1988; 167: 1737-1742.

47. Kankaanranta $H$, Ilmarinen $P$, Zhang X, Adcock IM, Lahti A, Barnes PJ et al. Tumour necrosis factor-alpha regulates human eosinophil apoptosis via ligation of TNF-receptor 1 and balance between NF-kappaB and AP-1. PloS One 2014; 9: e90298.
48. Huaux F, Gharaee-Kermani M, Liu T, Morel V, McGarry B, Ullenbruch M et al. Role of Eotaxin-1 (CCL11) and CC chemokine receptor 3 (CCR3) in bleomycin-induced lung injury and fibrosis. The American journal of pathology 2005; 167: 1485-1496.

49. Sumi Y, Hamid Q. Airway remodeling in asthma. Allergol Int 2007; 56: 341-348.

50. Foster PS, Mould AW, Yang M, Mackenzie J, Mattes J, Hogan SP et al. Elemental signals regulating eosinophil accumulation in the lung. Immunol Rev 2001; 179: 173-181.

51. Lora JM, Zhang DM, Liao SM, Burwell T, King AM, Barker PA et al. Tumor necrosis factoralpha triggers mucus production in airway epithelium through an IkappaB kinase betadependent mechanism. J Biol Chem 2005; 280: 36510-36517.

52. Pinho V, Souza DG, Barsante MM, Hamer FP, De Freitas MS, Rossi AG et al. Phosphoinositide-3 kinases critically regulate the recruitment and survival of eosinophils in vivo: importance for the resolution of allergic inflammation. $J$ Leuk Biol 2005; 77 : 800-810.

53. Perez DA, Vago JP, Athayde RM, Reis AC, Teixeira MM, Sousa LP et al. Switching off key signaling survival molecules to switch on the resolution of inflammation. Mediators Inflamm 2014; 2014: 829851.

54. Pollock JD, Williams DA, Gifford MA, Li LL, Du X, Fisherman J et al. Mouse model of X-linked chronic granulomatous disease, an inherited defect in phagocyte superoxide production. Nat Genet 1995; 9: 202-209.

55. Duffin R, Leitch AE, Sheldrake TA, Hallett JM, Meyer C, Fox S et al. The CDK inhibitor, R-roscovitine, promotes eosinophil apoptosis by down-regulation of Mcl-1. FEBS Lett 2009, 583: $2540-2546$.

56. Kurowska-Stolarska M, Kewin P, Murphy G, Russo RC, Stolarski B, Garcia CC et al. IL-33 induces antigen-specific IL-5+ T cells and promotes allergic-induced airway inflammation independent of IL-4. J Immunol 2008; 181: 4780-4790.

57. Marques PE, Oliveira AG, Pereira RV, David BA, Gomides LF, Saraiva AM et al. Hepatic DNA deposition drives drug-induced liver injury and inflammation in mice. Hepatology 2014; 61: 348-360.

58. Serra MF, Anjos-Valotta EA, Olsen PC, Couto GC, Jurgilas PB, Cotias AC et al. Nebulized lidocaine prevents airway inflammation, peribronchial fibrosis, and mucus production in a murine model of asthma. Anesthesiology 2012; 117: 580-591.

59. Arantes-Costa FM, Lopes FD, Toledo AC, Magliarelli-Filho PA, Moriya HT, Carvalho-Oliveira $\mathrm{R}$ et al. Effects of residual oil fly ash (ROFA) in mice with chronic allergic pulmonary inflammation. Toxicol Pathol 2008; 36: 680-686.

60. Sousa LP, Carmo AF, Rezende BM, Lopes F, Silva DM, Alessandri AL et al. Cyclic AMP enhances resolution of allergic pleurisy by promoting inflammatory cell apoptosis via inhibition of PI3K/Akt and NF-kappaB. Biochem Pharmacol 2009; 78: 396-405.

61. Strath M, Warren DJ, Sanderson CJ. Detection of eosinophils using an eosinophil peroxidase assay. Its use as an assay for eosinophil differentiation factors. J Immunol Methods 1985; 83: 209-215.

62. Olsen PC, Ferreira TP, Serra MF, Farias-Filho FA, Fonseca BP, Viola JP et al. Lidocainederivative JMF2-1 prevents ovalbumin-induced airway inflammation by regulating the function and survival of T cells. Clin Exp Allergy 2011; 41: 250-259.

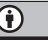

Cell Death and Disease is an open-access journal published by Nature Publishing Group. This work is licensed under a Creative Commons Attribution 4.0 International Licence. The images or other third party material in this article are included in the article's Creative Commons licence, unless indicated otherwise in the credit line; if the material is not included under the Creative Commons licence, users will need to obtain permission from the licence holder to reproduce the material. To view a copy of this licence, visit http://creativecommons.org/licenses/by/4.0 